ISSN 1978-3000

\title{
Suplementasi Serbuk Kulit Nenas serta Mineral Cu dan Zn dalam Ransum dan Pengaruhnya terhadap Kandungan Antioksidan Susu Kambing
}

\author{
Supplementation of Pineapples Rind with $\mathrm{Cu}$ and $\mathrm{Zn}$ Mineral in Diet and Its Effect on \\ Antioxidant Concentration of Goat Milk
}

\author{
Mardalena \\ Fakultas Peternakan Universitas Jambi, Kampus Pinang Masak, \\ Jl. Raya Jambi - Ma. Bulian Km 15 Ma. Jambi 36136 Jambi, \\ E-mail: lenadjamas@yahoo.co.id
}

\begin{abstract}
A study of in vivo on utilization of feed supplement (FS) containing of pineapples rind (PR) $+25 \mathrm{ppm} \mathrm{Zn}$ and $10 \mathrm{ppm} \mathrm{Cu}$ minerals as antioxidant source to increase antioxidant and cholesterol of milk. Etawah dairy goats in the second lactation with an average milk production of 0.467 liters head- 1 day- 1 were used in this experiment. The base diet was elephant grass (Pennisetum purpureum) and the commercial concentrate containing $12.6 \%$ crude protein $\left(500 \mathrm{~g} \mathrm{head}^{-1} \mathrm{day}^{-1}\right)$. The treatments were elephant grass + concentrate as control (C), C+ FS containing $2.4 \% \mathrm{PR}+$ Min, C + FS containing 3.6\% PR + Min and C + FS containing $4.8 \% \mathrm{PR}+\mathrm{Min}$. Variables of of dairy goat milk observed were milk yield and 4\% FCM yield, lactose, fat, protein and antioxidant. Data were analyzed using Anova. Results showed that there were differences $(\mathrm{p}<0.05)$ among treatments on milk lactose and milk antioxidant, but no differences ( $\mathrm{P}>0.05)$ were found on milk yield, 4\% FCM (Fat Corrected Milk) yield, milk fat, and milk protein. As conclusion of this study was the supplementation of pineapple rind $4.8 \%$ and $25 \mathrm{ppm} \mathrm{Zn}+10 \mathrm{ppm} \mathrm{Cu}$ minerals as antioxidant source did increase antioxidant of goat milk.
\end{abstract}

Keywords :Supplementation, pineapples rind, antioxidant

\begin{abstract}
ABSTRAK
Suatu penelitian in vivopenggunaan pakan suplemen yang mengandung serbuk kulit nenas (SKN) + mineral Zn 25 ppm dan $\mathrm{Cu} 10$ ppm sebagai sumber antioksidan dilakukan untuk meningkatkan antioksidan dan kolesterol susu. Kambing perah Etawah yang berada pada laktasi kedua dengan produksi rata-rata 0.467 liter per ekor per hari digunakan pada penelitian ini. Ransum basal terdiri dari rumput gajah (Pennisetum purpureum) dan konsentrat komersial mengandung $12.6 \%$ protein kasar (500 g/ekor/hari). Perlakuan terdiri dari rumput gajah +konsentrat sebagai kontrol (C), C+ pakan suplemen mengandung 2.4\% SKN+mineral, C+pakan suplemen mengandung 3.6\% SKN+mineral dan $\mathrm{C}+$ pakan suplemen mengandung $4.8 \% \mathrm{SKN}+$ mineral. Variabel yang diamati adalah produksi susu dan produksi susu 4\%FCM, laktosa susu, lemak susu, protein susu dan antioksidan susu kambing. Data dianalisa menggunakan Anova. Hasil penelitian menunjukkan bahwa terdapat perbedaan yang nyata $(\mathrm{p}<0.05)$ diantara perlakuan terhadap laktosa susu dan antioksidan susu, tetapi tidak terdapat perbedaan yang nyata $(\mathrm{P}>0.05)$ terhadap produksi susu, produksi susu 4\%FCM (Fat Corrected Milk), lemak susu, dan protein susu. Kesimpulan hasil penelitian ini adalah suplementasi serbuk kulit nanas $4.8 \%$ dan mineral Zn 25 ppm+ Cu10 ppm sebagai sumber antioksidan meningkatkan antioksidan susu kambing.
\end{abstract}

Kata kunci: Suplementasi, serbuk kulit nenas, antioksidan.

\section{PENDAHULUAN}

Antioksidan yang terkandung di dalam makanan sangat dibutuhkan untuk melindungi sel-sel tubuh dari serangan radikal bebas. Fungsi antioksidan di dalam tubuh adalah untuk meningkatkan kekebalan dengan mempertahankan struktur dan fungsi sel. Sistem kekebalan tubuh yang rendah akan menurunkan efisiensi produksi ternak sehingga akan meningkatkan morbiditas dan mortalitas (McDowell, 2002). Antioksidan alami tersebut dapat membantu melawan efek merugikan yang disebabkan oleh oksigen 
reaktif (ROS) dan radikal bebas dalam tubuh yang dapat menyebabkan penyakit degeneratif pada manusia seperti kanker, penyakit jantung dan penyakit serebrovaskular (Wresburger, 2002). Efek pertahanan dari antioksidan alami terdapat dalam makanan terutama pada buah dan sayuran yang terdiri dari tiga kelompok utama yaitu vitamin, fenolat dan karotenoid. Asam askorbat dan fenolat dikenal sebagai antioksidan hidrolifik, sedangkan karotenoid dikenal sebagai antioksidan lipofilik (Winarsi, 2007).

Buah nenas (Ananas comosus L. Merr) merupakan buah yang sangat bergizi karena mengandung vitamin $\mathrm{C}$ yang tinggi dan antioksidan alami yang dapat menghambat perkembangan kondisi klinis tertentu termasuk penyakit jantung dan kanker pada manusia (Mahdavi et al., 2010). Buah ini juga mengandung senyawa fenolik dan $\beta$-karoten (Gardner, et al., 2000; Charoensiri et al., 2009; Kongsuwan et al., 2009). Nenas selain dikonsumsi sebagai buah segar, juga banyak digunakan sebagai bahan baku industri pertanian untuk berbagai macam pengolahan seperti selai, manisan, sirup, dan lain-lain maka menghasilkan kulit yang cukup banyak sebagai hasil sampingan, sehingga kulit nenas juga mempunyai potensi mengandung antioksidan (Mardalena, 2012). Menurut Winarsi (2007) kandungan antioksidan pada kulit buah-buahan lebih tinggi dari pada daging buah bagian dalam. Hasil analisis fitokimia yang dilaporkan Mardalena et al. (2011) menunjukkan bahwa kulit buah nenas mengandung total antioksidan sebesar 38,95 $\mathrm{mg} / 100 \mathrm{~g}$ dengan komponen bioaktif berupa vitamin C sebesar 24,40 mg/100 g, beta karoten 59,98 ppm, flavonoid 3,47\%, kuersetin $1,48 \%$, fenol 32,69 ppm dan saponin 5,29\%. Hasil analisis komposisi zat makanan limbah nenas kering menunjukkan bahwa kandungan bahan kering $(78,82 \%)$, lemak $(1,72 \%)$ protein kasar $(4,81 \%)$, BETN $(57,74 \%)$, selulosa $(11,43 \%)$ dan hemiselulosa $(23,11 \%)$.

Menurut Howard et al. (2002) sumber antioksidan terdapat pada berbagai sayuran, buah-buahan dan rempahrempahan. Potensinya terdapat pada komponen fenolnya. Menurut Panovskai et al. (2005) senyawa flavonoid dan polifenol mempunyai aktivitas sebagai antioksidan (Huda-Faujan et al., 2009), yang bersamasama dengan vitamin $\mathrm{C}$ dan karotenoid melindungi jaringan tubuh akibat stres oksidatif (Scalbert and Williamson, 2000).

Pada kambing perah, $\mathrm{Zn}$ harus disuplai secara kontinyu sebab hanya sedikit yang dapat disimpan dalam tubuh dalam bentuk tersedia atau siap pakai. Defisiensi Zn dapat menyebabkan parakeratosis, pengeluaran saliva berlebihan, libido rendah, konsumsi menurun dan kehilangan bobot badan pada kambing. Kebutuhan minimum Zn per hari untuk kambing belum ditetapkan, namun dosis 10 ppm merupakan batas paling minimum (NRC, 2007). Menurut King (2000) Zn dapat disimpan dalam bentuk metalloenzim (MT) dan merupakan pemakan radikal bebas yang baik. Metalloenzim merupakan protein intraseluler yang memiliki ikatan kuat dengan $\mathrm{Zn}$ dan $\mathrm{Cu}$. 
Penelitian ini dilakukan untuk mengevaluasi pengaruh penggunaan serbuk kulit nenas serta mineral $\mathrm{Zn}$ dan $\mathrm{Cu}$ sebagai pakan suplemen yang mengandung antioksidan dalam ransum yang diharapkan dapat meningkatkan kandungan antioksidan susu kambing perah Peranakan Etawah (PE).

\section{MATERI DAN METODE PENELITIAN}

Serbuk kulit nenas dibuat melalui proses yaitu dengan mengumpulkan kulit nenas yang berasal dari limbah hasil industri pembuatan dodol dan selai nenas yang ada di Kabupaten Muaro Jambi. Kulit nenas dicincang halus, kemudian dikeringkan dengan oven pada suhu 40 $50{ }^{\circ} \mathrm{C}$ dan selanjutnya dilakukan penggilingan.

Penelitian menggunakan kambing perah Peranakan Etawah (PE) laktasi II dengan produksi susu rata-rata 0,467 liter per ekor. Hijauan yang diberikan berupa rumput gajah yang diberikan dua kali sehari. Konsentrat diberikan sebanyak 500 gram/ekor/hari. Pakan suplemen terdiri dari serbuk kulit nenas (SKN) dan mineral mikro (mineral Zn 25 ppm dan mineral $\mathrm{Cu} 10$ ppm) (Mardalena et al., 2014). Pakan suplemen dicampurkan dengan pakan konsentrat sesuai dengan perlakuan. Rancangan yang digunakan dalam penelitian ini adalah Rancangan Acak Kelompok yang terdiri atas 4 perlakukan pemberian pakan suplemen dengan 4 ulangan yang terdiri dari : R0 = Hijauan + konsentrat, $\mathrm{R} 1=\mathrm{R} 0+\mathrm{PS}(\mathrm{SKN} 2,4 \%+$ mineral $\mathrm{Zn}$ dan $\mathrm{Cu}), \mathrm{R} 2=\mathrm{R} 0+\mathrm{PS}(\mathrm{SKN}$
$3,6 \%+$ mineral $\mathrm{Zn}$ dan $\mathrm{Cu}), \mathrm{R} 3=\mathrm{R} 0+$ PS (SKN 4,8\%+ Mineral Zn dan $\mathrm{Cu})$.Peubah yang diamati adalah komponen produksi susu harian, produksi susu 4\% FCM, kualitas susu yang meliputi protein susu, lemak susu, laktosa susu dan antioksidan susu.

\section{Analisis Data}

Data dianalisis dengan Anova satu arah menggunakan program SAS 9.1.3. (SAS Institute Inc. North Caroline, 2007). Perbedaan antar perlakuan diuji menggunakan uji lanjut Duncan's Multiple Range Test (DMRT).

\section{HASIL DAN PEMBAHASAN}

\section{Produksi Susu Kambing PE}

Produksi susu merupakan tujuan utama yang diharapkan dari pemeliharaan ternak perah. Data pengaruh perlakuan terhadap rata-rata produksi susu harian dan produksi 4\% FCM dapat dilihat pada Tabel 1. Produksi susu kambing PE setelah diberi pakan yang mengandung suplemen sebagai sumber antioksidan tidak nyata ( $\mathrm{P}>0.05)$ meningkatkan produksi susu harian dan produksi susu 4\% FCM. Hal ini karena ransum percobaan yang diberikan menghasilkan asam propionat yang lebih rendah $(29,72 \mathrm{mM})$ dibanding asam asetat $(90,45 \mathrm{mM})$ di dalam rumen sehingga menghasilkan pertambahan bobot badan yang signifikan pada kambing perah (Mardalena, 2012)

Pada penelitian ini produksi susu harian berkisar antara 0,266 - 0,406 liter/ekor/hari dan produksi susu 4\% FCM berkisar antara 0,36 -0,53 liter/ekor/hari. 
Produksi susu yang didapat relatif rendah dibanding hasil penelitian Rumetor (2008) yaitu $0,42-0,83 \mathrm{~kg} / \mathrm{ekor} / \mathrm{hari}$ karena perbedaan sumber antioksidan yang diberikan. Rendahnya produksi susu pada penelitian ini disebabkan berbagai faktor antara lain masa laktasi dan frekuensi pemerahan. Semua ternak percobaan yang digunakan baru berumur 1,5 tahun atau laktasi kedua dengan frekuensi pemerahan satu kali sehari. Nudda et al., (2002) melaporkan bahwa penurunan frekuensi pemerahan dari dua kali menjadi sekali sehari akan mengurangi produksi susu dan mempengaruhi komposisi susu. Ditambahkan oleh Bremel (2008), produksi susu pada laktasi pertama biasanya lebih rendah dibanding laktasi berikutnya. Pada kambing yang mempunyai produksi susu yang tinggi, akan terjadi kehilangan produksi susu sebesar $26-36 \%$ jika dilakukan pemerahan satu kali sehari (Boutinaud et al., 2003).

Tabel 1. Produksi susu kambing PE dengan pemberian pakan suplemen.

\begin{tabular}{|c|c|c|c|c|c|}
\hline \multirow[t]{2}{*}{ Parameter } & \multirow[t]{2}{*}{ Minggu } & \multicolumn{4}{|c|}{ Perlakuan } \\
\hline & & R0 & $\mathrm{R} 1$ & $\mathrm{R} 2$ & R3 \\
\hline \multirow[t]{5}{*}{ Produksi Susu (liter/ekor/hari) } & 2 & 0,25 & 0,32 & 0,45 & 0,43 \\
\hline & 4 & 0,27 & 0,40 & 0,39 & 0.49 \\
\hline & 6 & 0,22 & 0,38 & 0,38 & 0,58 \\
\hline & 8 & 0,11 & 0,13 & 0,14 & 0,13 \\
\hline & Rataan & 0,27 & 0,31 & 0,38 & 0,41 \\
\hline $\begin{array}{ll}\text { Produksi } & \text { Susu }\end{array}$ & & & & & \\
\hline \multirow{4}{*}{ (liter/ekor/hari) } & 2 & 0,36 & 0,43 & 0,42 & 0,55 \\
\hline & 4 & 0,39 & 0,41 & 0,57 & 0,62 \\
\hline & 6 & 0,35 & 0,33 & 0,34 & 0,46 \\
\hline & Rataan & 0,36 & 0,39 & 0,44 & 0,53 \\
\hline
\end{tabular}

Dari Tabel 1. terlihat bahwa pemberian suplemen tidak nyata $(\mathrm{P}>0,05)$ mempengaruhi produksi susu. Hal ini disebabkan saponin yg terkandung dalam suplemen belum mampu meningkatkkan konsentrasi asam propionat dalam rumen sebagai sumber utama pembentukan laktosa susu. Dzarnisa (2010) menambahkan bahwa produksi susu meningkat diakibatkan terjadi peningkatan aktivitas enzim sintetase kelenjar ambing sehingga penggunaan substrat glukosa untuk membentuk laktosa susu menjadi lebih efisien. Laktosa merupakan nutrien utama dalam susu yang bertanggung jawab mempertahankan keseimbangan tekanan osmotik antara darah dan lumen susu.
Produksi laktosa dapat mempengaruhi volume air susu yang dialirkan dalam lumen susu dan selanjutnya menentukan tingkat produksi susu yang dihasilkan.

\section{Kualitas Susu Kambing PE}

Tinggi rendahnya komposisi zat gizi dalam susu menggambarkan tinggi rendahnya kualitas susu yaang dihasilkan. Hasil analisis komposisi zat gizi dalam susu kambing PE yang diberi pakan suplemen yang mengandung antioksidan dapat dilihat pada Tabel 2. Kandungan protein susu berkisar antara 3,40 - 4,43\%. Kandungan zat gizi dalam susu erat kaitannya dengan ketersediaan komponen nutrien dalam darah untuk sintesis susu. 
Apabila dibandingkan dengan hasil penelitian Mateljan (2008) terhadap susu kambing pada umumnya, maka kandungan komponen protein dan laktosa relatif sama. Hal ini diantaranya karena faktor bangsa ternak dan pakan yang diberikan. Ditambahkan Bruhn (2006) bahwa jenis pakan mempengaruhi komposisi gizi susu yang dihasilkan kambing perah serta kualitas pakan akan mempengaruhi metabolisme dalam tubuh ternak sehingga akan mempengaruhi ketersediaan energi dan zat gizi untuk sintesis komponen susu. Hasil analisis keragaman menunjukan bahwa perlakuan pemberian suplemen nyata $(\mathrm{P}<0,05)$ meningkatkan laktosa susu namun tidak nyata $(\mathrm{P}>0,05)$ meningkatkan kadar protein dan lemak susu. Hal ini disebabkan peran antioksidan dalam pakan suplemen berupa saponin, flavonoid serta mineral $\mathrm{Zn}$ dan $\mathrm{Cu}$ selama proses metabolisme di dalam rumen. Saponin dapat menekan pembentukan populasi protozoa yang merugikan selama proses fermentasi dan flavonoid serta mineral $\mathrm{Zn}$ juga dapat meningkatkan kecernaan in vitro dalam rumen sehingga dihasilkan peningkatan KcBK, VFA total dan parsial sebagai sumber energi bagi ternak. Selama proses metabolisme di dalam rumen, terjadi peningkatan proporsi asam propionat secara nyata $(\mathrm{P}<0,05)$ akibat pemberian suplemen (Mardalena, 2012). Di dalam tubuh asam propionat dirubah menjadi glukosa darah yang merupakan sumber utama untuk pembentukan laktosa susu (Zhao dan Keating, 2007).

Menurut Paulina et al. (2008) kandungan protein susu bervariasi tergantung dari bangsa, produksi susu, tingkat laktasi, kualitas dan kuantitas pakan. Faktor yang paling besar pengaruhnya adalah produksi susu. Semakin tinggi produksi susu, kadar protein susu akan semakin rendah karena kecepatan sintesis protein susu pada umumnya meningkat dengan kecepatan yang lebih lambat. Hasil penelitian menunjukkan bahwa produksi susu tidak menghasilkan peningkatan begitu juga dengan kadar protein tidak menghasilkan peningkatan yang nyata. Hasil penelitian sama dengan pendapat Wang et al. (2010) bahwa pakan yang mengandung antioksidan tidak memberikan pengaruh terhadap kandungan protein, lemak, laktose, bahan kering dan bahan kering tanpa lemak pada susu sapi perah. Hasil yang berbeda dilaporkan olehVazquezAnon et al. (2008) bahwa agrado plus yang merupakan antioksidan dalam pakan yang diberikan pada sapi laktasi dapat meningkatkan konsumsi bahan kering, produksi susu FCM dan lemak susu. Perubahan komposisi lemak susu berhubungan dengan menurunnya oksidasi dan biohydrogenation rumen akibat meningkatnya aktifitas antioksidan enzim plasma dalam proses fisiologis dalam tubuh sapi

Produksi susu berkorelasi negatif dengan kadar lemak susu sehingga pada penelitian ini dihasilkan produksi susu yang rendah dan kadar lemak yang tinggi walaupun perlakuan pakan suplemen tidak mempengaruhi kadar lemak susu. Lemak susu merupakan komponen yang paling sensitif terhadap perubahan nutrisi pada ternak. Kadar lemak susu kambing 
dipengaruhi oleh pakan hijauan, semakin tinggi pakan hijauan yang diberikan maka semakin tinggi pula kadar lemak susu (Zurriyanti et al., 2011). Kadar lemak susu dalam penelitian adalah $6,29-6,71 \%$. Hasil ini lebih tinggi dari yang dilaporkan Sudono et al. (2003) yaitu sebesar 3,45 \%. Kadar lemak susu merupakan komponen yang paling mudah berubah dan sangat tergantung pada kadar serat makanan. Serat makanan yang rendah akan menghasilkan asetat yang rendah. Menurut Sukarini (2006), bahwa ternak yang diberi pakan tambahan konsentrat akan menurunkan kadar lemak susu dan pakan yang hanya terdiri dari hijauan memiliki kadar lemak yang lebih tinggi dibanding pakan yang ditambah dengan konsentrat.

Pada penelitian ini dihasilkan kadar lemak yang tinggi dibanding hasil penelitian lain karena selama bioproses dalam rumen terjadi peningkatan asam asetat yang lebih tinggi dibanding asam propionat sehingga kadar lemak yang terbentuk lebih tinggi walaupun antar perlakuan tidak menghasilkan perbedaan yang nyata. Kadar lemak dipengaruhi oleh asam asetat yang berasal dari hijauan (Ace dan Wahyuningsih, 2010 dan Ramadhan et al., 2013). Hijauan yang dimakan oleh ternak, kemudian mengalami proses fermentatif didalam rumen oleh mikroba rumen. Hasil proses fermentatif berupa VFA. VFA terdiri dari propionat, asetat, dan butirat. Asetat masuk ke dalam darah dan diubah menjadi asam lemak, kemudian akan masuk ke dalam sel-sel sekresi ambing dan menjadi lemak susu.

Tabel 2. Pengaruh pakan suplemen terhadap kualitas susu kambing PE

\begin{tabular}{|c|c|c|c|c|c|}
\hline \multirow{2}{*}{ Parameter } & \multirow{2}{*}{ Minggu } & \multicolumn{4}{|c|}{ Perlakuan } \\
\hline & & R0 & $\mathrm{R} 1$ & $\mathrm{R} 2$ & $\mathbf{R 3}$ \\
\hline \multirow{4}{*}{$\begin{array}{l}\text { Protein susu } \\
(\%)\end{array}$} & 0 & 3,45 & 3,61 & 3,33 & 4,61 \\
\hline & 4 & 3,58 & 3,50 & 3,46 & 4,32 \\
\hline & 8 & 3,36 & 3,31 & 3,45 & 4,33 \\
\hline & Rataan & 3,46 & 3,47 & 3,41 & 4,43 \\
\hline \multirow{4}{*}{$\begin{array}{c}\text { Lemak susu } \\
(\%)\end{array}$} & 0 & 6,32 & 6,67 & 6,75 & 6,71 \\
\hline & 4 & 6,22 & 6,67 & 6,67 & 5,69 \\
\hline & 8 & 6,32 & 6,67 & 6,72 & 5,80 \\
\hline & Rataan & 6,29 & 6,70 & 6,71 & 6,10 \\
\hline \multirow{4}{*}{$\begin{array}{c}\text { Laktosa susu } \\
(\%)\end{array}$} & 0 & 4,57 & 4,37 & 4,95 & 4,86 \\
\hline & 4 & 4,16 & 4,58 & 4,85 & 5,26 \\
\hline & 8 & 4,09 & 4,03 & 5,37 & 5,35 \\
\hline & Rataan & $4,75^{\mathrm{b}}$ & $4,97^{\mathrm{b}}$ & $5,07^{\mathrm{b}}$ & $5,47^{\mathrm{a}}$ \\
\hline
\end{tabular}

Keterangan : Nilai dengan superskrip yang berbeda pada baris yang sama menunjukkkan berbeda nyata $(\mathrm{P}<0,05)$.

R0 : Hijauan + konsentrat, R1 : R0 + Pakan Suplemen 3\%, R2: R0 + Pakan Suplemen 4,5\%,

R3 : R0 + Pakan Suplemen $6 \%$.

Lemak susu terbentuk dari campuran trigliserida dengan asam lemak rantai pendek. Lemak susu terutama berasal dari asam asetat yang dihasilkan pada rumen dalam proses metabolisme pakan yang mengandung hemiselulosa (Larson, 1985). Rantai pendek asam lemak yang dibuat dalam ambing berasal dari rantai pendek asam lemak volatil, terutama asetat dan butirat, yang dihasilkan dari fermentasi serat dalam rumen. Asam lemak rantai panjang tidak dibuat dalam ambing, tetapi berasal dari asam lemak dari makanan, mikroba rumen dan lemak tubuh. Asam lemak rantai pendek dan 
rantai-panjang bergabung akan untuk membentuk lemak susu (Ondarza, 2001).

Pada Tabel 2. Terlihat rataan kadar protein dan laktosa susu hasil penelitian masing-masing adalah 3,40 - 4,43\% dan $4,75-5,47 \%$. Selama penelitian terlihat terjadinya peningkatan kadar protein sebesar 3,13 - 23,25\% dan kadar laktosa sebesar 4,43 - 13,16\% pada perlakuan yang mengandung pakan suplemen dibanding kontrol. Hal ini disebabkan dengan semakin tingginya taraf pemberian pakan suplemen menyebabkan tingginya kandungan komponen bioaktif dalam pakan sehingga akan memberikan efek positif terhadap komponen zat gizi susu. Hal ini berhubungan dengan proses biosintesis dalam rumen terutama yang berhubungan dengan

Pemberian pakan suplemen yang mengandung antioksidan dapat meningkatkan $(\mathrm{P}<0,05)$ kadar laktosa susu. Kadar laktosa susu pada penelitian ini sedikit lebih tinggi dari hasil penelitian Mateljan (2008) pada susu kambing pada umumnya. Menurut Larson (1985) kadar laktosa dalam susu relatif konstan, berhubungan dengan pemeliharaan tekanan osmotik susu pada proses pembentukan dan pengeluaran susu. Menurut Paulina et al. (2008) laktosa berbeda dengan protein dan lemak dimana konsentrasi laktosa dalam susu tidak banyak dipengaruhi oleh produksi susu karena laktosa disintesis dan diekskresi dengan kecepatan yang sama dengan produksi susu.

\section{Antioksidan Susu}

Susu yang digunakan untuk konsumsi atau untuk produk olahan harus memiliki kapasitas antioksidan tinggi sehingga produk susu sampai ke konsumen dengan kualitas yang tinggi (Havemose et al., 2006).

Tabel 3. Pengaruh pakan suplemen terhadap antioksidan dan kolesterol susu.

\begin{tabular}{lccccc}
\hline Parameter & Minggu & \multicolumn{3}{c}{ Perlakuan } \\
\cline { 2 - 6 } & & R0 & R1 & R2 & R3 \\
\hline Antioksidan susu & 0 & 19,79 & 23,73 & 28,43 & 28,83 \\
$(\mathrm{mg} / 100 \mathrm{~mL})$ & 8 & 24,87 & 24,74 & 28,64 & 32,27 \\
\cline { 2 - 6 } & Rataan & $24,87^{\mathrm{b}}$ & $24,24^{\mathrm{b}}$ & $28,64^{\mathrm{a}}$ & $30,55^{\mathrm{a}}$ \\
\hline
\end{tabular}

Keterangan : Nilai dengan superskrip yang berbeda pada baris yang sama menunjukkan berbeda nyata $(\mathrm{P}<0,05)$.

R0 : Hijauan + konsentrat, R1 : R0 + Pakan Suplemen 3\%， R2 : R0 + Pakan Suplemen 4,5\%， R3 : R0 + Pakan Suplemen 6\%

Pada Tabel 3. terlihat bahwa pemberian pakan suplemen nyata $(\mathrm{P}<0,05)$ meningkatkan kandungan antioksidan susu. Meningkatnya antioksidan dalam susu karena pakan suplemen mengandung antioksidan berupa vitamin $\mathrm{C}$, betakaroten, flavonoid, saponin dan fenol.

Kisaran antioksidan susu pada penelitian ini adalah 24,873 $32,272 \mathrm{mg} / 100 \mathrm{~mL}$. Selama penelitian terjadi peningkatan antioksidan susu pada perlakuan yang mengandung pakan suplemen sebesar 20,52 - 23,33\% dibanding kontrol. Terlihat bahwa antioksidan susu tertinggi perlakuan R3 yaitu pemberian pakan suplemen $6 \%$.

Pakan suplemen disamping mengandung komponen bioaktif yang terdapat pada serbuk kulit nenas berupa flavonoid dan vitamin, juga peran mineral 
$\mathrm{Zn}$ dan $\mathrm{Cu}$ secara nyata meningkatkan antioksidan susu dibanding perlakuan kontrol. Ini menunjukkan bahwa komponen bioaktif seperti flavonoid dan vitamin $\mathrm{C}$ dapat melindungi asam lemak dari oksidasi (Zielinska et al., 2001), dan senyawa ini memiliki kemampuan untuk mengurangi pembentukan radikal bebas dan menangkap radikal bebas yang dapat menyebabkan degradasi asam lemak dalam tubuh (Pazos et al, 2005; Juntachote et al, 2007). Perubahan komposisi susu berhubungan dengan menurunnya oksidasi lemak dan biohydrogenasi rumen akibat meningkatnya aktifitas antioksidan enzim plasma dalam proses fisiologis dalam tubuh ternak. Aoki et al. (2010) melaporkan bahwa suplementasi trehalose yang mengandung komponen bioaktif dalam pakan sapi perah dapat menurunkan lipid peroksidasi dan menekan stres oksidatif serta dapat meningkatkan antioksidan dalam susu.

\section{SIMPULAN}

Dari hasil penelitian dapat disimpulkan bahwa suplementasi serbuk kulit nenas yang ditambah mineral Zn dan $\mathrm{Cu}$ dalam ransum dapat meningkatkan kandungan antioksidan dalam susu kambing perah peranakan etawah.

\section{UCAPAN TERIMA KASIH}

Ucapan terima kasih disampaikan kepada Ditjen Dikti Kemendiknas Jakarta yang telah membiayai penelitian ini melalui Program Hibah Bersaing tahun 2010 dan Kepala Balai Penelitian Ternak
Ciawi Bogor yang telah memberi kesempatan untuk melaksanakan penelitian ini. Semoga Allah SWT selalu melimpahkan rahmat dan hidayahNya. Amien.

\section{DAFTAR PUSTAKA}

Ace, I. S dan Wahyuningsih. 2010. Hubungan variasi pakan terhadap mutu susu segar di Desa Pasirbuncir Kecamatan Caringin Kabupaten Bogor. Jurnal Penyuluhan Pertanian Vol. 5 No. 1.

Aoki, N., S. Furukawa, K.Sato, Y. Kurokawa, S.Kanda, Y. Takahashi, H. Mitsuzumi and H.Itabashi. 2010. Supplementation of the diet of dairy cows with trehalose results in milk with low lipid peroxide and high antioxidant content. J. Dairy Sci. 93:4189-4195.

Akers, R. M. 2002. Lactation and The Mamary Gland. Iowa: Iowa State Press.

Boutinaud, M., C. Rousseau, D. H. Keisler and H. Jammes. 2003. Growth hormone and milking frequency act differently on goat mammary gland in late lactation. J. Dairy Sci. 86:509-520.

Bremel, R.D. 2008. Biology of Lactation. London: W.H. Freeman and Co.

Bruhn, J.C. 2006. Dairy Goat Milk Composition. Colorado: Agriculture Research Service, Departement of Agricultural.

Castillo, C., J. Hernandez, A. Bravo, M. Lopez- Alonso, V. Pereira, and J. L. Benedito. 2005. Oxidative status 
during late pregnancy andearly lactation in dairy cows. Vet. J.169:286-292.

Charoensiri, R., Kongkachuichai, R., Suknicom S. and Sungpuag, P. 2009. Betacarotene, lycopene, and alphatocopherol contents of selected Thai fruits. Food Chemistry. 113, 202207.

Dzarnisa. 2010. Peningkatan Produksi Susu Periode Laktasi Berikutnya Melalui Kombinasi Injeksi bovine somatotropin (bST) dan Suplementasi Seng selama Masa Kering pada Sapi Peranakan Fries Holland (PFH). Disertasi. Sekolah Pascasarjana IPB, Bogor.

Gardner, P.T., White, T.A.C., McPhail, D.B. and G.G. Duthie. 2000. The relative contributions of vitamin $\mathrm{C}$, carotenoids and phenolics to the antioxidant potential of fruit juices. Food Chemistry. 68, 471-474.

Havemose, M.S., M. R. Weisbjerg, W. L. P. Bredie, H. D. Poulsen and J. H. Nielsen. 2006. Oxidative stability of milk influenced by fatty acids, antioxidants and copper derived from feed. J. Dairy Sci. 89:19701980.

Howard, L.R., N. Pandjaitan, T. Morelock, and M.I. Gil. 2002. Antioxidant capacity and phenolic content of spinach as affected by genetics and growing season. J. Agric. Food Chem. 50: 5891 - 5896.

Huda-Faujan, N., A. Noriham, A. S. Norrakiah, and A. S. Babji. 2009. Antioxidant activity of plants methanolic extracts containing phenolic compounds. Afric. J. Biotech. 8: 484-489.

Juntachote, T., E. Berghofer, S. Siebenhandl and F. Bauer. 2007. Antioxidative effects of added dried holy basil and its ethanolic extracts on susceptibility grounds pork to lipid oxidation. Food Chem. 100:129-135.

King, J.C. 2000. Determinants of maternal zinc status during pregnancy. American Jurnal of Clinical Nutrition. 71:1334 - 1343.

Kongsuwan, P. Suthiluk, T. Theppakorn, V. Srilaong and S. Setha. 2009. Bioactive compounds and antioxidant capacities of phulae and nanglae pineapple As. J. Food AgInd. Special Issue, S44-S50.

Larson, BL. 1985. Biosynthesis and Cellular Secretion of Milk. Dalam : Larson BL. Editor. Lactation. Iowa: Iowa State Press.

Mahdavi, R., Z. Nikniaz, M. Rafraf and A. Jouyban. 2010. Determination and comparison of total polyphenol and vitamin $\mathrm{C}$ contents of natural fresh and commercial fruit juices. Pakistan Journal of Nutrition 9 (10): 968-972.

Mardalena, L. Warly, E. Nurdin, R.W.R. Ningrat and Farizal. 2011. Milk quality of dairy goat after giving feed supplement as antioxidant source. J. Ind. Trop. Animal Agric. 36 (3): 205-211.

Mardalena. 2012. Evalusi Pakan Suplemen Sebagai Sumber Antioksidan dan Pengaruhnya terhadap Respon Fisiologis dan Produktifitas 
Kambing Perah Peranakan Etawah. Disertasi S3 Unand.

Mardalena, L. Warly, E. Nurdin, R.W.R. Ningrat and S. Novianti. 2013. Feed supplement evaluation of pineapple rind and micro mineral as antioxidant source to rumen fermentation of Etawah dairy goats. Proceedings of The $4^{\text {th }}$ International Conference on Sustainable Animal Agriculture for Developing Countries. $27-31$ July 2013. Lanzhou, China.

Mardalena, S. Novianti, Yurleni and U. Amri. 2014. Evaluation of feed supplement as antioxidant source to rumen ecology. Pak. J. Nutr., 13 (7): 381-385.

Mateljan, G. 2008. Milk Goat. USA: The GM Foundation.

McDowell, L.R. 2002. Recent advances in minerals and vitamins on nutrition of lactating cows. Pak. J. Nutr. 1: 8-19.

NRC, National Research Council. 2007. Nutrient requirements of small ruminants. National Academy Press, Washington DC, USA.

Nudda, A., R. Bencini, S. Mijatovic, and G. Pulina. 2002. The yield and composition of milk in Sarda, Awassi, and Merino sheep milked unilaterally at different frequencies.

J. Dairy Sci. 85:2879-2884.

Ondorza, M.B. 2001. Milk Component. Milk production.com.htm November 2010).

Panovskai, T. K., S. Kulevanova and M. Stefova. 2005. In vitro antioxidant activity of some Taucrium species
Lamiaceae. Acta Pharm. 55:207214.

Paulina, G., A. Nudda, G. Battacone, S. Fancellu and A.H.D. Francesconi. 2008. Nutrient and Quality of Goat's Milk. In: A. Cannas, G. Paulina Editor. Dairy Goat Feeding and Nutrition. Department of Animal Science Univ. of Sasari. Pp. 1-30.

Pazos M., J. M. Gallardo, J.L. Torres and I. Medina. 2005. Activity of grafe polyphenols as inhibitor of the oxidation of fish lipids and frozen fish muscle. Food Chem. 92:547557.

Ramadhan, B. G., T. H. Suprayogi dan A. Sutiyah. 2013. Tampilan produksi susu dan kadar lemak susu kambing Peranakan Ettawa akibat pemberian pakan dengan imbangan hijauan dan konsentraat yang berbeda. Animal Agriculture Journal. Vol. 2, No. 1: 353-361.

Rumentor, S.D. 2008. Suplementasi Daun Bangun-Bangun (Coleus amboinicus Lour) dan ZincVitamin E dalam Ransum untuk Memperbaiki Metabolisme dan Produksi Susu Kambing Peranakan Etawah. Disertasi. Sekolah Pascasarjana Institut Pertanian Bogor, Bogor.

SAS 9.1.3. Portable. 2007. SAS/STAT User's Guide. SAS Institute Incorporation Cary. North Carolina.

Scalbert A. and G. Williamson. 2000. Dietary intake and bioavaibility of 
polyphenols. J. Nutr. 130: 2073S2085S.

Sudono A., R.F. Rosdiana, dan B.S. Setiawan. 2003. Beternak Sapi Perah Secara Intensif. Jakarta: Agromedia, Jakarta.

Sukarini. 2006. Produksi dan kualitas air susu kambing Peranakan Ettawa yang diberi tambahan Urea Molases Blok dan atau dedak padi pada awal laktasi. Animal Production. Vol. 8, No. 3: 196-205. Vázquez-Añón, J. Nocek, G. Bowman, T. Hampton, C. Atwell, P. Vazquez and T. Jenkins. 2008. Effects of feeding oxidized fat with or without dietary antioxidants on nutrient digestibility, microbial nitrogen, and fatty acid metabolism. J. Dairy Sci. 90:43614867.

Winarsi, H. 2007. Antioksidan Alami dan Radikal Bebas. Potensi dan Aplikasinya dalam Kesehatan. Penerbit Kanisius.
Wresburger J.H. 2002. Lifestyle, health and disease prevention: The underlying mechanism. Eur. J. Cancer Prev. S2: 1 -7.

Zhao, F.Q. and A. F. Keating. 2007. Expression and regulation of glucose transporters in the bovine mammary gland. J. Dairy Sci. 90 (E. Suppl.): E76-E86.

Zielinska, M., A. Kostrzewa, E. Ignatowicz and J. Budzianowski. 2001. The Flavonoid, quercetin and isorhamneti, 3-0-acylglucosides diminish neutrophil oxidative metabolism and lipid peroxidation. Acta Biochim. Pol. 48:183-189.

Zurriyanti, Y., R. R. Noor dan R. R. A. Maheswari. 2011. Analisis molekuler genotipe kappa kasein (K-Kasein) dan komposisi susu kambing Peranakan Etawa, Saanen dan Persilangannya. JITV Vol. 16 No. 1 :61-70. 